\title{
Evaluation of Antileishmanial Activity of Albaha Medicinal Plants against Leishmania amazonensis
}

\author{
Saeed S. Al-Sokari, ${ }^{1}$ Nasser A. Awadh Ali, ${ }^{2}$ Lianet Monzote, ${ }^{3}$ and Mohamed A. Al-Fatimi ${ }^{4}$ \\ ${ }^{1}$ Department of Biology, Faculty of Sciences, Al Baha University, Saudi Arabia \\ ${ }^{2}$ Pharmacognosy Department, Faculty of Clinical Pharmacy, Al Baha University, Saudi Arabia \\ ${ }^{3}$ Departamento de Parasitología, Instituto de Medicina Tropical Pedro Kourí, La Habana, Cuba \\ ${ }^{4}$ Pharmacognosy Department, Faculty of Pharmacy, Aden University, P.O. Box 5411, Ma'alla, Aden, Yemen
}

Correspondence should be addressed to Nasser A. Awadh Ali; alinasser9678@yahoo.com

Received 1 July 2015; Accepted 4 August 2015

Academic Editor: Yu-Ping Tang

Copyright (C) 2015 Saeed S. Al-Sokari et al. This is an open access article distributed under the Creative Commons Attribution License, which permits unrestricted use, distribution, and reproduction in any medium, provided the original work is properly cited.

\begin{abstract}
Sixteen methanolic extracts obtained from thirteen plant species, selected either from ethnobotanical or chemotaxonomical data, were screened for their antileishmanial activity against Leishmania amazonensis. The cytotoxic activity against normal peritoneal macrophages from normal BALB/c mice was also determined. Eight extracts had $\mathrm{IC}_{50}$ values ranging from $<12.5$ to $37.8 \mu \mathrm{g} / \mathrm{mL}$ against promastigotes. Achillea biebersteinii flower, Euphorbia helioscopia, and Solanum incanum leaf extracts showed antileishmanial activities with $\mathrm{IC}_{50}$ between $<12.5-26.9 \mu \mathrm{g} / \mathrm{mL}$ and acceptable selectivity indices of $8-5$. The other leishmanicidal plant extracts, with $\mathrm{IC}_{50}$ ranging from 18.0 to $29.5 \mu \mathrm{g} / \mathrm{mL}$, exhibited low selectivity indices.
\end{abstract}

\section{Introduction}

Leishmaniasis is distributed worldwide, especially in tropical and subtropical areas and more than 12 million people are currently infected. About 20000 to 30000 deaths occur annually. Cutaneous leishmaniasis (CL) is the most common form of leishmaniasis and causes skin lesions, mainly ulcers. About 95\% of CL cases occur in the Americas, the Mediterranean basin, the Middle East, and Central Asia. Over twothirds of new CL cases occur in 6 countries: Afghanistan, Algeria, Brazil, Colombia, Iran, and Syria. An estimated 0.7 million to 1.3 million new cases occur worldwide annually $[1,2]$.

In Saudi Arabia, the disease was first described in 1973 by Morsy and Shoura [3]. Currently, CL is common in the human population in different localities, including the Eastern Province of Saudi Arabia and in particular the AlHassa Oasis that is a known endemic area for CL [4]. At the moment, no good conventional treatments for CL in most countries are available. The conventional drugs are very toxic and not $100 \%$ effective. Therefore, there is an urgent need to discover new therapeutic agents. Traditional medicine knowledge can be useful to open new ways in the search of new antileishmanial agents. A number of published studies have demonstrated that many plant extracts exhibited activity against Leishmania parasites [5-8]. Some reports were published about the antiprotozoal activity of Saudi medicinal plants [5, 9-11]. In this study, the plant species were selected either from ethnobotanical or chemotaxonomical data [12]. It is noteworthy to mention that to the best of our knowledge, this study represents the first report on antileishmanial activity for some of the tested plants. The aim of this study was to investigate the antileishmanial activity of the 16 methanol extracts from 13 selected plant species from Albaha region, against Leishmania amazonensis.

\section{Material and Methods}

2.1. Plant Materials. The plant material was collected in March-April 2014 from different locations in Albahah town and outskirts of Albaha, except myrrh oleo gum resins that were purchased from the herbal shops under the name (Somali Myrrha) (Table 1). The plants were taxonomically 
TABLE 1: Selected plants studied, ethnobotanical information and characteristics.

\begin{tabular}{|c|c|c|c|c|}
\hline Species & Plant family (voucher specimen no) & $\begin{array}{l}\text { Part tested }^{a} \\
\text { (yield in \%) }\end{array}$ & Local name & Traditional uses \\
\hline Achillea biebersteinii Afan. & Asteraceae (CP-101) & $\mathrm{Fl}(1.5)$ & Thafra & $\begin{array}{l}\text { Antispasmodic and for }{ }^{1} \text { kidney } \\
\text { inflammation }\end{array}$ \\
\hline Achillea biebersteinii Afan. & (CP-101) & $\mathrm{L}(2.6)$ & Thafra & $\begin{array}{l}\text { As antispasmodic and for kidney } \\
\text { inflammation }\end{array}$ \\
\hline $\begin{array}{l}\text { Calotropis procera (Aiton) } \\
\text { W.T.Aiton }\end{array}$ & Asclepiadaceae (CP-091) & $\mathrm{L}(4.2)$ & Alashur & For treating leprosy and filariasis \\
\hline Chenopodium murale L. & Amaranthaceae (CP-081) & $\mathrm{F}(7.3)$ & Jkheara & Leishmaniasis $^{1}$ \\
\hline Commiphora myrrha L. & Burseraceae (CP-071) & Resin (70) & Somali mir & $\begin{array}{l}\text { Gum used for treating } \\
\text { leishmaniasis }^{2}\end{array}$ \\
\hline Dodonaea viscosa Jacq. & Sapindaceae (CP-061) & $\mathrm{L}(3.5)$ & Shath & $\begin{array}{l}\text { For treating chronic ulcer, burns, } \\
\text { leishmaniasis }^{2}\end{array}$ \\
\hline Euphorbia helioscopia L. & Euphorbiaceae (CP-051) & $\mathrm{AP}(4.2)$ & Al-dehin & Antiseptic \\
\hline Lavandula dentata $\mathrm{L}$. & Lamiaceae (CP-041) & $\mathrm{AP}(2.9)$ & Al-shiah & $\begin{array}{l}\text { As antispasmodic, antiseptic } \\
\text { when the leaves chewed }\end{array}$ \\
\hline Pulicaria crispa SCH.BIP & Asteraceae (CP-102) & $\mathrm{AP}(3.1)$ & Arararabi & Antimalarial, stomach disorders ${ }^{2}$ \\
\hline Punica granatum $\mathrm{L}$. & Punicaceae (CP-011) & $\mathrm{Fl}(2.5)$ & Al-roman & Anthelmintic, antiseptic ${ }^{2}$ \\
\hline Ruta chalepensis L. & Rutaceae (CP-121) & $\mathrm{L}(5.2)$ & Al-shathab & Antimicrobial $^{2}$ \\
\hline Solanum incanum L. & Solanaceae (CP-131) & $F(7.6)$ & Al-hadak & Antiseptic $^{2}$ \\
\hline Solanum incanum L. & Solanaceae (CP-132) & $\mathrm{L}(3.9)$ & Al-hadak & $\begin{array}{l}\text { Leaves as dressing for healing } \\
\text { wounds, paste of fruits for } \\
\text { treating leishmaniasis }\end{array}$ \\
\hline $\begin{array}{l}\text { Verbesina encelioides (Cav.) } \\
\text { Benth \& Hook. f. ex A. Gray }\end{array}$ & Asteraceae (CP-021) & $\mathrm{L}(3.7)$ & Safeara & Wounds, skin diseases ${ }^{2}$ \\
\hline $\begin{array}{l}\text { Withania somnifera (L.) } \\
\text { Dunal }\end{array}$ & Solanaceae (CP-011) & $\mathrm{F}(4.6)$ & Alobeb & Chronic dermatitis $^{2}$ \\
\hline Withania somnifera & Solanaceae (CP-011) & $\mathrm{L}(8.5)$ & Alobeb & \\
\hline
\end{tabular}

identified at the Faculty of Science, Department of Botany, Aden University, Yemen. Voucher specimens of the plant material are deposited at the Pharmacognosy Department, Faculty of Clinical Pharmacy, Albaha University, Saudi Arabia.

2.2. Preparation of Extracts. Air-dried and powdered plant material (10 g) was extracted under shaking at room temperature with $\mathrm{MeOH}(4 \times 100 \mathrm{~mL})$. The obtained extracts were filtered and evaporated to dryness in vacuo at $40^{\circ} \mathrm{C}$. The yields of each dried extract were calculated in \%. The resulting dried crude extracts were stored at $4^{\circ} \mathrm{C}$. For testing, the extracts were dissolved in dimethylsulfoxide (DMSO) at $20 \mathrm{mg} / \mathrm{mL}$.

\subsection{Antileishmanial and Cytotoxicity Assays}

2.3.1. Parasite Cultures. Strain MHOM/77BR/LTB0016 of L. amazonensis, provided by Immunology Department at Oswaldo Cruz Foundation (FIOCRUZ) from Brazil, was used. Parasites were routinely isolated from normal BALB/c mice lesions and maintained as promastigotes at $26^{\circ} \mathrm{C}$ in Schneider's medium (SIGMA, St. Louis, MO, USA) containing $10 \%$ heat-inactivated fetal bovine serum (HFBS) (SIGMA, St. Louis, MO, USA) and corresponding antibiotics (100 $\mu \mathrm{g}$ of streptomycin/mL, $100 \mathrm{U}$ penicillin/mL). Parasites were not used after the tenth passage to carry out in vitro experiments.

2.3.2. Antipromastigote Assay. Fifty microliters of Schneider's medium with HFBS and antibiotics was distributed in each well of a 96 -well plate. In the first one, additional $48 \mu \mathrm{L}$ of medium was added as well as $2 \mu \mathrm{L}$ of extracts. Then, five dilutions $1: 2$ were carried out taking $50 \mu \mathrm{L}$ each time to test concentrations of the extracts ranging from 12.5 to $200 \mu \mathrm{g} / \mathrm{mL}$ and a final volume was completed to $100 \mu \mathrm{L}$ after addition of $50 \mu \mathrm{L}$ of parasites at $4 \times 10^{5}$ promastigotes $/ \mathrm{mL}$ in logarithmic phase. Also, parasites treated with DMSO or pentamidine (Richet, Buenos Aires, Argentina) were also included as controls. Plates were sealed with parafilm and incubated at $26^{\circ} \mathrm{C}$ during 72 hours. Then, $20 \mu \mathrm{L}$ of a solution of 3 [4,5-dimethylthiazol-2-yl]-2,5-diphenyltetrazolium bromide (MTT) (SIGMA, St. Louis, MO, USA) at $5 \mathrm{mg} / \mathrm{mL}$ prepared and filtered in the moment of use was added in each well. An additional incubation of 4 hours was performed, the supernatant was eliminated, and the formazan crystals were dissolved with $100 \mu \mathrm{L}$ of DMSO. The optical density was determined using a spectrophotometer (Sirio S Reader, 2.40 , Italy), at a test wavelength of $560 \mathrm{~nm}$, using $630 \mathrm{~nm}$ as reference wavelength $[13,14]$. The median inhibitory 
concentration $\left(\mathrm{IC}_{50}\right)$ was obtained from linear dose-response curves fit to data by means of the linear equation model. The evaluations were performed in triplicate and the results are expressed as mean \pm standard deviation.

2.3.3. Cytotoxicity Assay. The cytotoxic median concentration $\left(\mathrm{CC}_{50}\right)$ of the extracts was also determined on normal peritoneal macrophages from normal BALB/c mice [13]. Resident macrophages were collected from peritoneal cavities of animals in ice RPMI 1640 medium (SIGMA, St. Louis, Mo, USA) supplemented with antibiotics. Suspension was seeded at 30000 cells/well and incubated for 2 hours at $37^{\circ} \mathrm{C}$ in $5 \%$ $\mathrm{CO}_{2}$. Nonadherent cells were removed by washing and $50 \mu \mathrm{L}$ of medium complemented with $10 \%$ of HFBS and antibiotics was added. Additional $48 \mu \mathrm{L}$ was distributed in first well along with $2 \mu \mathrm{L}$ of tested extracts. Plant extracts were tested at 5 concentrations $(200,100,50,25$ and $12.5 \mu \mathrm{g} / \mathrm{mL})$ to establish a full dose-titration and determination of the $\mathrm{IC}_{50}$ (inhibitory concentration 50\%). The plate was incubated under the same conditions during 72 hours. Macrophages treated with DMSO or pentamidine were included as controls. Cells viability was determined using the colorimetric assay with MTT as previously described, where $15 \mu \mathrm{L}$ was added to each well, and $\mathrm{CC}_{50}$ was obtained from dose-response curves fit to data by means of the linear equation model. The evaluations were performed in triplicate and the results are expressed as mean \pm standard deviation.

Then, the selectivity index (SI) ratio was obtained from calculation: $\mathrm{CC}_{50}$ for macrophage $/ \mathrm{IC}_{50}$ for promastigotes [15]. Extracts with SI $\geq 5$ or with $\mathrm{IC}_{50}<12.5 \mu \mathrm{g} / \mathrm{mL}$ against promastigotes were selected for further experiments.

2.3.4. Antiamastigote Assay. The peritoneal macrophages were obtained as previously described and plated at $10^{6} / \mathrm{mL}$ in 24-Well Lab-Tek (Costar, USA). Nonadherent cells were removed by washing after incubation of 2 hours at $37^{\circ} \mathrm{C}$ in $5 \%$ $\mathrm{CO}_{2}$. Macrophages were then infected with stationary-phase of L. amazonensis promastigotes at $4: 1$ parasite/macrophage ratio and incubated again during 4 hours at the same conditions. Free parasites were removed by washing and $1000 \mu \mathrm{L}$ of RPMI completed medium was added in each well. In the first well, additional $990 \mu \mathrm{L}$ of medium and $10 \mu \mathrm{L}$ of the tested extracts were added and four dilutions $1: 2$ were carried out taking $1000 \mu \mathrm{L}$ each time, testing final concentrations between 12.5 and $100 \mu \mathrm{g} / \mathrm{mL}$. The plate was incubated at the same conditions for 48 hours [16]. Then, monolayer was fixed in absolute methanol, stained with Giemsa, and examined under light microscopy. Number of intracellular amastigotes and percent of infected macrophage were determined by counting 25 macrophages per sample, and the results were expressed as percent of reduction of the infection rate (obtained by multiplying the percentage of infected macrophages by the number of amastigotes per infected macrophages) in comparison to controls [15]. $\mathrm{IC}_{50}$ value was determined from the concentration-response linear curves. The evaluations were performed in triplicate and the results were expressed as mean \pm standard deviation.

\section{Results and Discussion}

Sixteen methanolic extracts of thirteen plant species belonging to ten families gathered from Albaha region were investigated for their in vitro antileishmanial activity. Table 1 gives the names of the plants, family, parts investigated, voucher specimen numbers, local names, yields in \%, and their traditional uses. Results of antileishmanial activity, cytotoxic effects on peritoneal macrophage from $\mathrm{BALB} / \mathrm{c}$ mice, and selectivity of methanolic extracts studied are summarized in Table 2. Out of the 16 methanol extracts tested against promastigote forms of L. amazonensis, three extracts showed promising activity with potent leishmanicidal activities and good selectivity indices: $A$. biebersteinii flower $\left(\mathrm{IC}_{50}=\right.$ $26.9 \mu \mathrm{g} / \mathrm{mL}$; SI = 5), E. helioscopia leaf $\left(\mathrm{IC}_{50}<12.5 \mu \mathrm{g} / \mathrm{mL}\right.$; SI $=8)$, and $S$. incanum leaf $\left(\mathrm{IC}_{50}=18.0 \mu \mathrm{g} / \mathrm{mL} ; \mathrm{SI}=8\right)$. In the case of extracts from Myrrh resin, W. somnifera and aerial parts of $P$. crispa also showed good antileishmanial activity but a low SI was observed. The rest of extracts tested were either inactive or nonspecific due to high cytotoxicity against normal peritoneal macrophages from $\mathrm{BALB} / \mathrm{c}$ mice (Table 2). The promising extracts were further tested against intracellular amastigotes of L. amazonensis, and four of these extracts were active (Table 2); in particular the extract of flowers from $A$. biebersteinii displayed the most promising activity.

Phytochemical studies of the genus Achillea have revealed the presence of a number of phytochemicals that exhibited antileishmanial activity. Santos et al. 2010 [17] reported the antileishmanial activity of an essential oil from the leaves and flowers of A. millefolium. Therefore, the antileishmanial activity of A. biebersteinii may be attributed either to the components of the essential oil [17] or alkamides that have been isolated from Achillea species and possess antileishmanial activity [18].

However, E. helioscopia has been the subject of abundant phytochemical and biological investigations, but there are no reports regarding its antileishmanial activity [19]. The plant is used traditionally in Saudi Arabia for removing warts and orally to dispel worms [20]. Several compounds have been isolated from E. helioscopia including jatrophone type diterpenoids and the flavones quercetin, and may be responsible for the leishmanicidal activity of the plant extract [21]. In agreement partially with our results, Duarte et al. reported antileishmanial activity for the stilbene piceatannol isolated from Euphorbia lagascae against promastigotes of $L$. donovani, L. infantum, and L. major with moderate activity [22]. Several triterpenoids isolated from Euphorbia resinifera and Euphorbia officinarum were found to possess antileishmanial activity [23].

Interestingly, antileishmanial activity was observed for $S$. incanum leaves. A number of Solanum species with antileishmanial activity have been reported [24-28]. It was found that the extract of $S$. torvum inhibited the proliferation of promastigotes of $L$. donovani [24]. The fruits of S. stramonifolium were shown to have marginal activity against amastigotes of $L$. amazonensis [25]. This activity may be attributed to the steroid derivative such as cilistol-A or steroidal alkaloids which form the main compounds in Solanum species [26, 27]. 
TABLE 2: Activity and cytotoxicity of plant extracts against L. amazonensis and peritoneal macrophage from BALB/c mice, respectively.

\begin{tabular}{|c|c|c|c|c|}
\hline Species (part tested ${ }^{\mathrm{a}}$ ) & $\begin{array}{c}\mathrm{IC}_{50}^{\mathrm{b}} \pm \mathrm{SD}^{\mathrm{c}}(\mu \mathrm{g} / \mathrm{mL}) \\
\text { Promastigotes } \\
\end{array}$ & $\begin{array}{c}\mathrm{CC}_{50}{ }^{\mathrm{d}} \pm \mathrm{SD}(\mu \mathrm{g} / \mathrm{mL}) \\
\text { Macrophage }\end{array}$ & $\mathrm{SI}^{\mathrm{e}}$ & $\begin{array}{c}\mathrm{IC}_{50} \pm \mathrm{SD}(\mu \mathrm{g} / \mathrm{mL}) \\
\text { Amastigotes }\end{array}$ \\
\hline A. biebersteinii (Fl) & $26.9 \pm 2.9$ & $131.3 \pm 6.1$ & 5 & $13.6 \pm 0.6$ \\
\hline A. biebersteinii (L) & $>200$ & - & - & - \\
\hline C. procera $(\mathrm{L})$ & $>200$ & - & - & - \\
\hline C. murale (F) & $>200$ & - & - & - \\
\hline Myrrha resin $(\mathrm{Re})$ & $17.5 \pm 0.01$ & $49.8 \pm 2.0$ & 3 & - \\
\hline D. viscosa $(\mathrm{L})$ & $>200$ & - & - & - \\
\hline E. helioscopia (AP) & $<12.5$ & $82.5 \pm 4.4$ & 7 & $31.1 \pm 3.9$ \\
\hline L. dentata (AP) & $>200$ & - & - & - \\
\hline P.crispa (AP) & $23.5 \pm 2.5$ & $79.0 \pm 7.3$ & 3 & - \\
\hline P.granatum $(\mathrm{Fl})$ & $>200$ & - & - & - \\
\hline R. chalepensis $(\mathrm{L})$ & $>200$ & - & - & - \\
\hline S. incanum (F) & $37.8 \pm 2.7$ & $174.6 \pm 6.9$ & 5 & $24.4 \pm 3.0$ \\
\hline S. incanum (L) & $18.0 \pm 2.8$ & $149.2 \pm 3.8$ & 8 & $31.0 \pm 3.8$ \\
\hline V.encelioides (L) & $>200$ & - & - & - \\
\hline W. somnifera $(\mathrm{F})$ & $29.5 \pm 1.0$ & $84.9 \pm 4.7$ & 3 & - \\
\hline W. somnifera $(\mathrm{L})$ & $20.3 \pm 6.8$ & $<12.5$ & 0 & - \\
\hline
\end{tabular}

${ }^{\mathrm{a}} \mathrm{AP}$, aerial parts; F: fruits; L: leaves; Re: resins; Fl: flowers.

${ }^{\mathrm{b}} \mathrm{IC}_{50}$ : Concentration of extract causing $50 \%$ growth inhibition.

${ }^{\mathrm{c}} \mathrm{SD}$ : Standard deviation.

${ }^{\mathrm{d}} \mathrm{CC}_{50}$ : Concentration of extract causing $50 \%$ of mortality of peritoneal macrophage from BALB/c.

${ }^{\mathrm{e}} \mathrm{SI}$ : Selectivity index. —: Not done.

The oleo gum resins (myrrh) of Commiphora species have long been used for health problems such as stomachache, colds, wounds, malaria, fever and as an antiseptic and against skin infections [28]. Previous studies on the Commiphora genus reported no antileishmanial activity of C. parvifolia and C. ornifolia [29]. This is the first report on the antileishmanial activity of myrrh oleo gum resins. Volatile oil of different Commiphora species was found to be rich in betaelemene, alpha-copaene, alpha-humulene, beta-selinene, and germacrene B. Commiphora oil rich in alpha-humulene may be responsible for antileishmanial activity [28, 30]. Antiplasmodial activities of C. opobalsamum and C. schimperi were previously reported [31].

W. somnifera fruits and leaf $\left(\mathrm{IC}_{50}\right.$ of 20.3 and $\left.29.5 \mu \mathrm{g} / \mathrm{mL}\right)$ exhibited, in the present study, more remarkable but nonselective antileishmanial activity than that reported previously and collected from India $\left(\mathrm{IC}_{50}: 63.0 \mu \mathrm{g} / \mathrm{mL}\right.$ ) [8]. However, similar activity with an extract collected from Oman was reported $\left(\mathrm{IC}_{50}: 22.1 \mu \mathrm{g} / \mathrm{mL}\right.$ ) [32]. The difference in the activity may be explained in the light of the presence and/or quantities of bioactive compounds in plants that are influenced by several factors including seasons, environment, plant-part used, intraspecies variations, and plant age. It was found that withaferin $\mathrm{A}$, the inhibitor of protein kinase $\mathrm{C}$, is responsible mainly for the higher activity of the plant $[8,33]$.

In our study, $P$. crispa extract exhibited more potent antileishmanial activity compared to the $P$. crispa extract reported in literature [34]. $P$. crispa species were found to possess antileishmanial activity. $P$. gnaphalodes essential oil and extract have good leishmanicidal effects and it seems that the leishmanicidal activity has been mostly related to the terpenoid constituents of the plant [35].

\section{Conclusion}

In conclusion, the evaluation of antileishmanial activity of 16 extracts from 13 plants of Albaha region against L. amazonensis has been reported for the first time and revealed that four extracts were found to have promising antileishmanial phytochemical constituents. In particular, the extract of $A$. biebersteinii was the most promising extract and should be further investigated using bioactivity-guided isolation of the active constituents. Moreover, the evaluation of antileishmanial activity confirms the ethnobotanical uses of certain plant extracts such as myrrh oleo gum resins and S. incanum.

\section{Conflict of Interests}

The authors declare no conflict of interests.

\section{References}

[1] World Health Organization (WHO), Control of the Leishmaniasis: Report of a Meeting of the WHO Expert Committee on the Control of Leishmaniasis, WHO, Geneva, Switzerland, 2010.

[2] WHO, "Leishmaniasis," WHO Fact Sheet 375, 2015, http://www .who.int/mediacentre/factsheets/fs375/en/.

[3] T. A. Morsy and M. I. Shoura, "Treatment of Saudi Arabian cutaneous leishmaniasis," Journal of Tropical Medicine and Hygiene, vol. 77, no. 3, p. 68, 1974. 
[4] T. T. Amin, H. I. Al-Mohammed, F. Kaliyadan, and B. S. Mohammed, "Cutaneous leishmaniasis in Al Hassa, Saudi Arabia: epidemiological trends from 2000 to 2010," Asian Pacific Journal of Tropical Medicine, vol. 6, no. 8, pp. 667-672, 2013.

[5] R. A. Mothana, N. M. Al-Musayeib, M. F. Al-Ajmi, P. Cos, and L. Maes, "Evaluation of the in vitro antiplasmodial, antileishmanial, and antitrypanosomal activity of medicinal plants used in Saudi and Yemeni traditional medicine," Evidence-Based Complementary and Alternative Medicine, vol. 2014, Article ID 905639, 7 pages, 2014.

[6] O. L. Adebayo, D. Suleman, and A. A. Samson, "Natural Products in antileishmanial drug discovery, a review," Journal of Asian Scientific Research, vol. 3, no. 2, pp. 157-173, 2013.

[7] S. K. Singh, S. Bimal, S. Narayan et al., "Leishmania donovani: assessment of leishmanicidal effects of herbal extracts obtained from plants in the visceral leishmaniasis endemic area of Bihar, India," Experimental Parasitology, vol. 127, no. 2, pp. 552-558, 2011.

[8] O. Kayser, A. F. Kiderlen, and S. L. Croft, "Natural products as antiparasitic drugs," Parasitology Research, vol. 90, no. 2, pp. S55-S62, 2003.

[9] N. M. Al-Musayeib, R. A. Mothana, S. Al-Massarani, A. Matheeussen, P. Cos, and L. Maes, "Study of the in vitro antiplasmodial, antileishmanial and antitrypanosomal activities of medicinal plants from Saudi Arabia," Molecules, vol. 17, no. 10, pp. 11379-11390, 2012.

[10] N. M. Al-Musayeib, R. A. Mothana, A. Matheeussen, P. Cos, and L. Maes, "In vitro antiplasmodial, antileishmanial and antitrypanosomal activities of selected medicinal plants used in the traditional Arabian Peninsular region," BMC Complementary \& Alternative Medicine, vol. 12, article 49, 2012.

[11] E. Abdel-Sattar, L. Maes, and M. M. Salama, "In vitro activities of plant extracts from Saudi Arabia against malaria, leishmaniasis, sleeping sickness and Chagas disease," Phytotherapy Research, vol. 24, no. 9, pp. 1322-1328, 2010.

[12] A. Gashash, Plants in Mountains of Sarah and Alhajaz, Albaha University Publisher, Albaha, Saudi Arabia, 2012.

[13] D. Sladowski, S. J. Steer, R. H. Clothier, and M. Balls, "An improved MIT assay," Journal of Immunological Methods, vol. 157, no. 1-2, pp. 203-207, 1993.

[14] A. Dutta, S. Bandyopadhyay, C. Mandal, and M. Chatterjee, "Development of a modified MTT assay for screening antimonial resistant field isolates of Indian visceral leishmaniasis," Parasitology International, vol. 54, no. 2, pp. 119-122, 2005.

[15] J. C. Delorenzi, M. Attias, C. R. Gattass et al., "Antileishmanial activity of an indole alkaloid from Peschiera australis," Antimicrobial Agents and Chemotherapy, vol. 45, no. 5, pp. 1349-1354, 2001.

[16] E. C. Torres-Santos, D. L. Moreira, M. A. C. Kaplan, M. N. Meirelles, and B. Rossi-Bergmann, "Selective effect of $2^{\prime}, 6^{\prime}$-dihydroxy-4' -methoxychalcone isolated from Piper aduncum on Leishmania amazonensis," Antimicrobial Agents and Chemotherapy, vol. 43, no. 5, pp. 1234-1241, 1999.

[17] A. O. Santos, A. C. Santin, M. U. Yamaguchi, L. E. R. Cortez, T. Ueda-Nakamura, and C. V. Nakamura, "Antileishmanial activity of an essential oil from the leaves and flowers of Achillea millefolium," Annals of Tropical Medicine and Parasitology, vol. 104, no. 6, pp. 475-483, 2010.

[18] J. B. Althaus, M. Kaiser, R. Brun, and T. J. Schmidt, "Antiprotozoal activity of Achillea ptarmica (Asteraceae) and its main alkamide constituents," Molecules, vol. 19, no. 5, pp. 6428-6438, 2014.

[19] E. M. Abou-El-Hamd, F. H. Mohamed-Elamir, M. F. M. Moustafa et al., "Euphorbia helioscopia: chemical constituents and biological activities," International Journal of Phytopharmacology, vol. 3, no. 1, pp. 78-90, 2012.

[20] M. Al-Shanwani, Plants in Saudi Arabia Used for Folk Medicine, King Abdul Aziz City for Science and Technology, 1996.

[21] R. S. Patil, M. S. Patil, S. S. Kshirsagar, P. S. Chaudhari, J. P. Bayas, and R. J. Oswal, "Synthetic and natural products against leishmaniasis-a review," World Journal of Public Health Sciences, vol. 1, no. 1, pp. 7-22, 2012.

[22] N. Duarte, O. Kayser, P. Abreu, and M. J. U. Ferreira, “Antileishmanial activity of piceatannol isolated from Euphorbia lagascae seeds," Phytotherapy Research, vol. 22, no. 4, pp. 455-457, 2008.

[23] N. Mazoir, A. Benharref, M. Bailén, M. Reina, A. GonzálezColoma, and R. A. Martínez-Díaz, "Antileishmanial and antitrypanosomal activity of triterpene derivatives from latex of two euphorbia species," Zeitschrift fur Naturforschung C, vol. 66, no. 7-8, pp. 360-366, 2011.

[24] D. J. Hubert, N. Céline, N. Michel et al., "In vitro leishmanicidal activity of some Cameroonian medicinal plants," Experimental Parasitology, vol. 134, no. 3, pp. 304-308, 2013.

[25] Y. Estevez, D. Castillo, M. T. Pisango et al., "Evaluation of the leishmanicidal activity of plants used by Peruvian Chayahuita ethnic group," Journal of Ethnopharmacology, vol. 114, no. 2, pp. 254-259, 2007.

[26] V. C. Filho, C. Meyre-Silva, R. Niero et al., "Evaluation of antileishmanial activity of selected brazilian plants and identification of the active principles," Evidence-Based Complementary and Alternative Medicine, vol. 2013, Article ID 265025, 7 pages, 2013.

[27] M. Abreu Miranda, R. F. J. Tiossi, M. R. Dasilva et al., "In vitro leishmanicidal and cytotoxic activities of the glycoalkaloids from Solanum lycocarpum (Solanaceae) fruits," Chemistry \& Biodiversity, vol. 10, no. 4, pp. 642-648, 2013.

[28] T. Shen, G.-H. Li, X.-N. Wang, and H.-X. Lou, "The genus Commiphora: a review of its traditional uses, phytochemistry and pharmacology," Journal of Ethnopharmacology, vol. 142, no. 2, pp. 319-330, 2012.

[29] R. A. Mothana, N. M. Al-Musayeib, A. Matheeussen, P. Cos, and L. Maes, "Assessment of the in vitro antiprotozoal and cytotoxic potential of 20 selected medicinal plants from the island of soqotra," Molecules, vol. 17, no. 12, pp. 14349-14360, 2012.

[30] L. Monzote, O. Alarcón, and W. N. Setzer, "Antiprotozoal activity of essential oils," Agriculturae Conspectus Scientificus, vol. 77, no. 4, pp. 167-175, 2012.

[31] F. A. Abbas, S. M. Al-massarany, S. Khan, T. A. Al-howiriny, J. S. Mossa, and E. A. Abourashed, "Phytochemical and biological studies on Saudi Commiphora opobalsamum L," Natural Product Research, vol. 21, no. 5, pp. 383-391, 2007.

[32] M. D. R. Camacho, J. D. Phillipson, S. L. Croft, P. N. Solis, S. J. Marshall, and S. A. Ghazanfar, "Screening of plant extracts for antiprotozoal and cytotoxic activities," Journal of Ethnopharmacology, vol. 89, no. 2-3, pp. 185-191, 2003.

[33] N. Sen, B. Banerjee, B. B. Das et al., "Apoptosis is induced in leishmanial cells by a novel protein kinase inhibitor withaferin A and is facilitated by apoptotic topoisomerase I-DNA complex," Cell Death and Differentiation, vol. 14, no. 2, pp. 358-367, 2007. 
[34] J. El-On, L. Ozer, J. Gopas et al., "Antileishmanial activity in Israeli plants," Annals of Tropical Medicine and Parasitology, vol. 103, no. 4, pp. 297-306, 2009.

[35] G. R. Asghari, F. Zahabi, A. Eskandarian, H. Yousefi, and M. Asghari, "Chemical composition and leishmanicidal activity of Pulicaria gnaphalodes essential oil," Research Journal of Pharmacognosy, vol. 1, no. 4, pp. 27-33, 2014. 

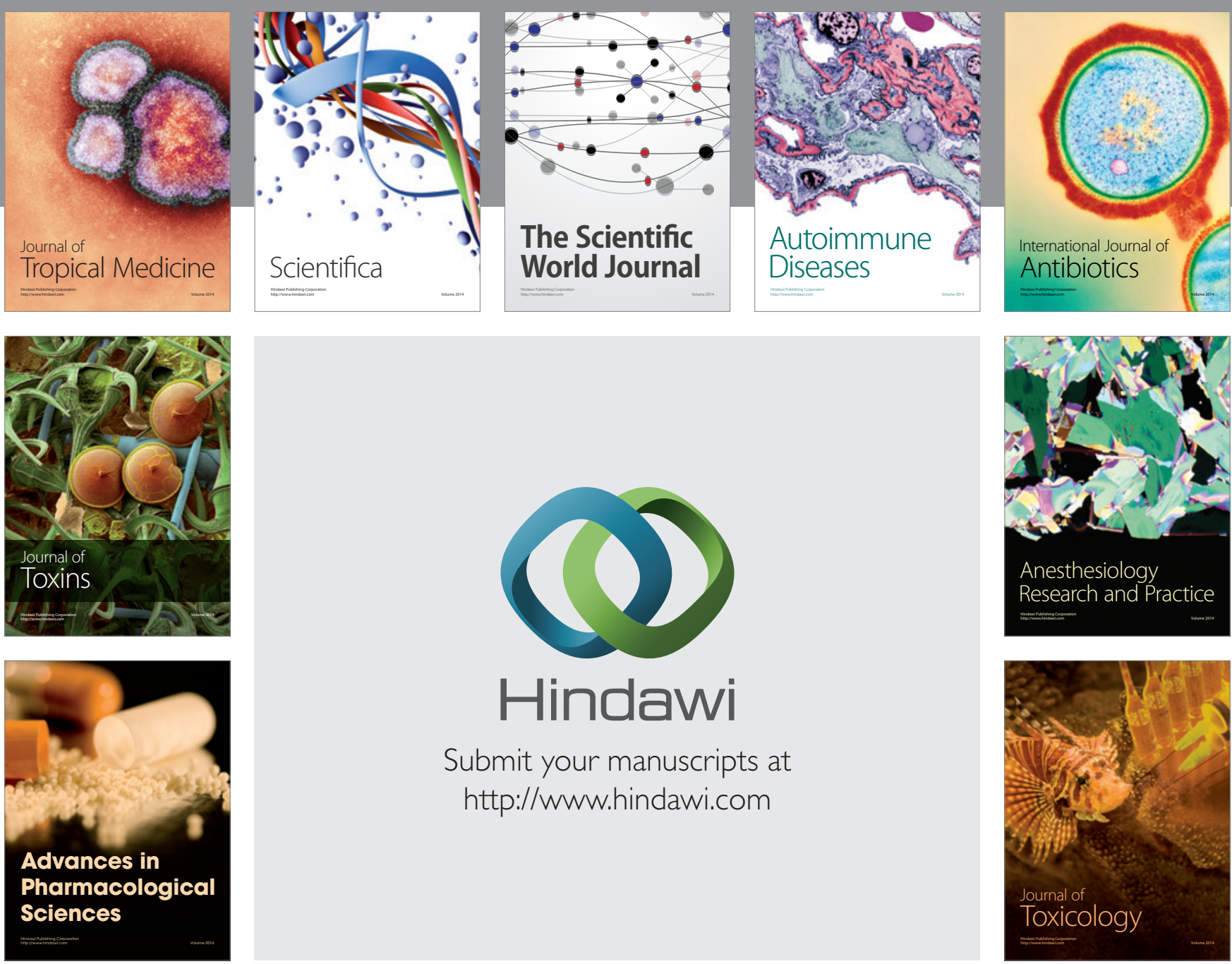

\section{Hindawi}

Submit your manuscripts at

http://www.hindawi.com
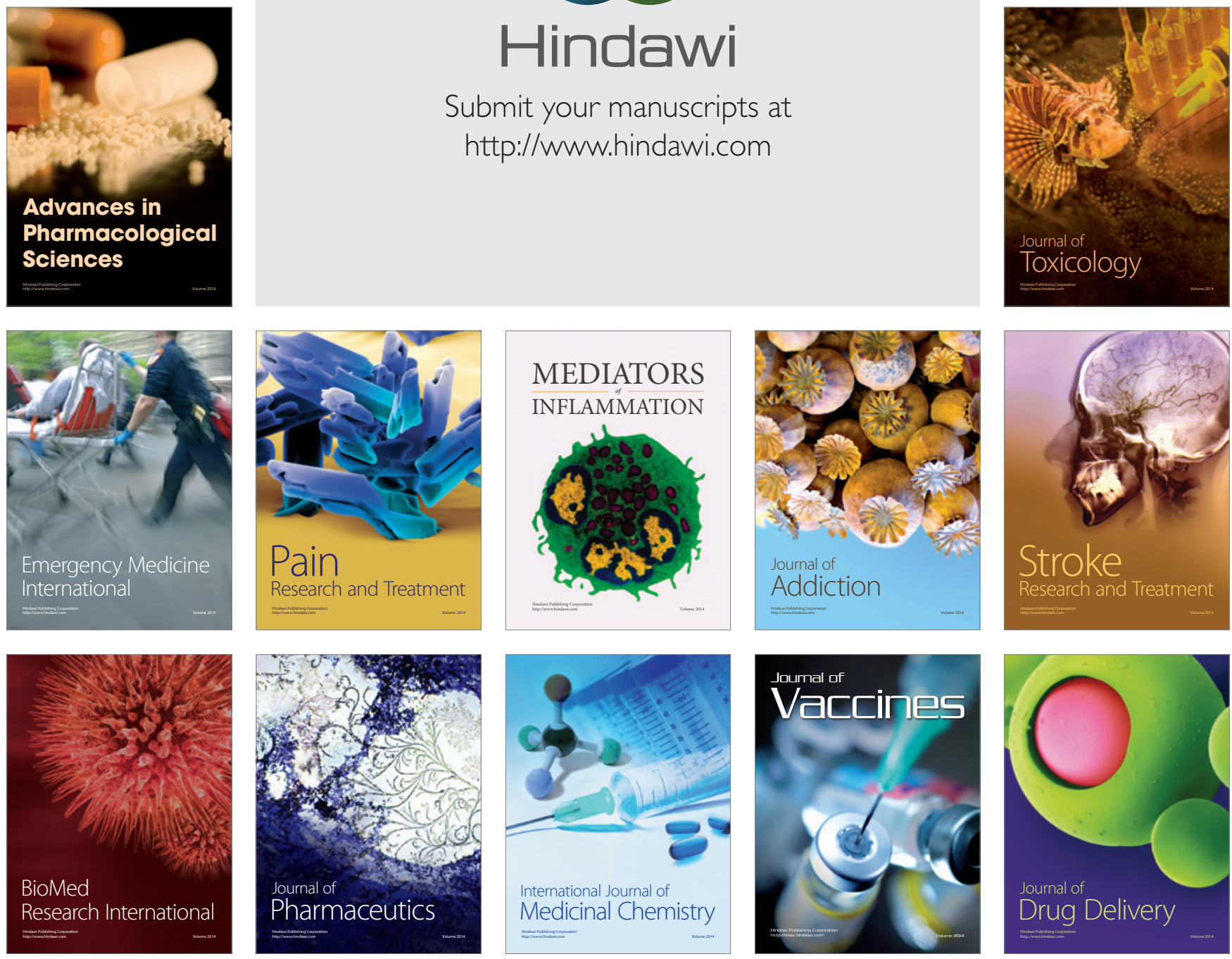